\title{
ELECTROMETALLURGY: ELECTROCHEMICAL, ECONOMIC AND ENVIRONMENTAL (3E) ASPECTS*
}

\author{
Perica Paunović, Svetomir Hadži Jordanov \\ Faculty of Technology and Metallurgy, University Ss. Cyril and Methodius, \\ Skopje, Republic of Macedonia \\ pericap@tmf.ukim.edu.mk
}

This paper is concerned with electrolysis processes aimed for production and refining of metals. This engineering field is named electrometallurgy. The main aspects of electrometallurgy such as electrochemical, energetic/economic and environmental ones are given. The peculiarity of electrorefining and electrowining in both aqueous electrolytes and molten salts are shown. The impact of energetic parameters, such as cell voltage and current efficiency on the economic justification of the electrolysis process is analyzed. It is emphasized that electrolysis is considerably cleaner technology than the pyrometallurgical production and refining of metals.

Key words: electrometallurgy; electrorefining; electrowining; aqueous electrolytes; molten salts; specific energy consumption.

\section{ЕЛЕКТРОМЕТАЛУРГИЈА: \\ ЕЛЕКТРОХЕМИСКИ ЕКОНОМСКИ И ЕКОЛОШКИ (3Е) АСПЕКТИ}

Во трудот се обработени процесите на електролиза за добивање и рафинирање на металите. Ова инженерско подрачје е наречено електрометалургија. Прикажани се основните аспекти на електрометалургијата-електрохемиските, енергетските/економските и еколошките. Исто така се прикажани особеностите на електрорафинацијата и електродобивањето на металите во водни раствори. Дадена е анализа на влијанието на енергетските параметри (напон на ќелија и искористување на струјата), врз економичноста на процесот на електролиза. Истакнато е дека електролитското добивање и рафинирање на металите се почисти технологии од оние при пирометалуршко добивање.

Клучни зборови: електрометалургија; електрорафинација; електродобивање; водени електролити; растопени соли; специфична потрошувачка на енергија. 


\section{ELECTROCHEMICAL ASPECTS}

\subsection{Electrometallurgy - Electrolysis}

Electrometallurgy deals with the use of electrical energy for production of pure metals by electrolysis. Electrometallurgy is usually the last stage in metal production after corresponding pyro- or hydrometallurgical operations. The process within the metal is produced by its aqueous salt as a last stage of the hydrometallurgical operations, is known as electrowining. Electrolytic purification of the crude metal produced by pyrometallurgical operations is known as electrorefination. Both processes are based on electrolysis, i.e. on the process in which forced electrons exchange of the matter occurs. Electrolysis, in some cases, is an irreplaceable way for production or refination of some metals. For example, aluminum can not be produced by pyrometallurgical procedure. Electrorefination of metals is unique process considering the level of metal purity, energy consumption as well as possibility for extraction of precious metal.

\subsection{Electrolysis cell}

Basic consisting elements of the electrolytic cell are shown in the simplified scheme in Figure 1. Two electronic conductors - electrodes (anode and cathode), an ionic conductor (electrolyte) and an energy source (battery) are necessary to perform electrolysis. In the electrolysis cell electrode reactions are non-spontaneous, i.e. they are forced by an external source of energy. So, reduction of the metal ions to pure metal (production or refination of metal) is enabled. For efficient electrolysis, the above elements have to satisfy some criteria. So, electrodes have to:

- be made by an appropriate material that promotes corresponding electrode reactions and exhibits good long-term stability and is environmental friendly;

- be appropriately processed in order to remove electrode products easily. Cathodic edges should be rounded off to prevent dendritic growth;

- be appropriately arranged into the cell for better volume efficiency. The shorter cathode-anode distance, the lower the Ohmic drop in the cell and consequently the lower energy consumption. On the other side, grown deposit on the cathode may cause short cut if the electrodes are too close.

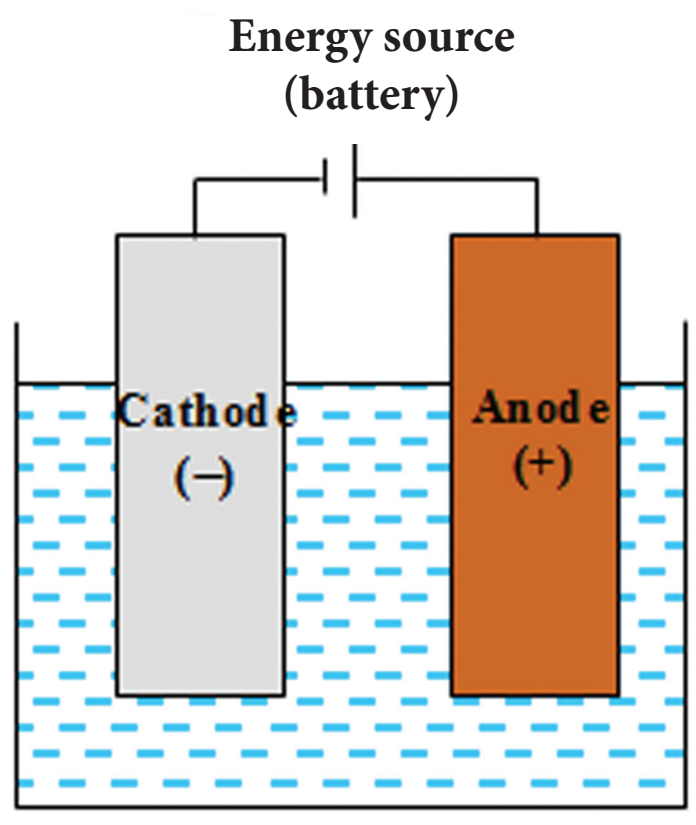

Fig. 1. Simplified scheme of the electrochemical cell

The electrolyte should contain:

- compound of the ion - participant in the electrode reaction;

- compounds that provide optimal electrical conductivity, corresponding acidity/ alkality and/or complex forming ability;

- corresponding additives for regulation of the surface tension, to optimize the diffusion potential, to provide better adhesion of the deposit over the cathodic substrate, to reach better optical and mechanical properties of the deposit;

- in some cases - mechanical components, e.g. thin oil layer or inert plastic balls in order to reduce electrolyte evaporation; 
- additives for optimizing density and viscosity in the case of the molten salt electrolysis.

The source of energy should be:

- properly designed to provide voltage and current output high enough for performing electrolysis;

- equipped with voltage regulation system;

- long-term stable.

The electrolysis cell has to be:

- prepared by a material having good chemical, thermal and mechanical stability. Traditional materials are wood, glass, concrete, stainless metals/alloys, while the recent ones are various polymer materials or coatings;

- equipped to shoulder electrodes (whose weight can reach even tens of tones) and to supply them with electricity;

- equipped for heating/cooling, stirring/ circulation and filling/emptying the electrolyte;

\subsection{Electrorefination vs. electrowining}

Depending on the input materials in the cell, electrolysis is aimed to produce or refine the metals. In the case of electrorefination, anodes are prepared by a raw metal produced by pyrometallurgical process. So, the basic metal ions originate by dissolving of the anode and further, they reduce on the cathode where the final product is highly-pure metal. In this case, there are soluble anodes which are the main source of basic metal ions, while the electrolyte possesses basic metal ions in quantity only to maintain sufficient concentration to avoid deposition of impurities on the cathode. In the case of electrowining the source of basic metal ions is the electrolyte. The anode does not dissolve during this process. On the anode some other anodic reaction occurs, e.g. oxygen or chlorine evolution. For this reason they are called non-soluble anodes.

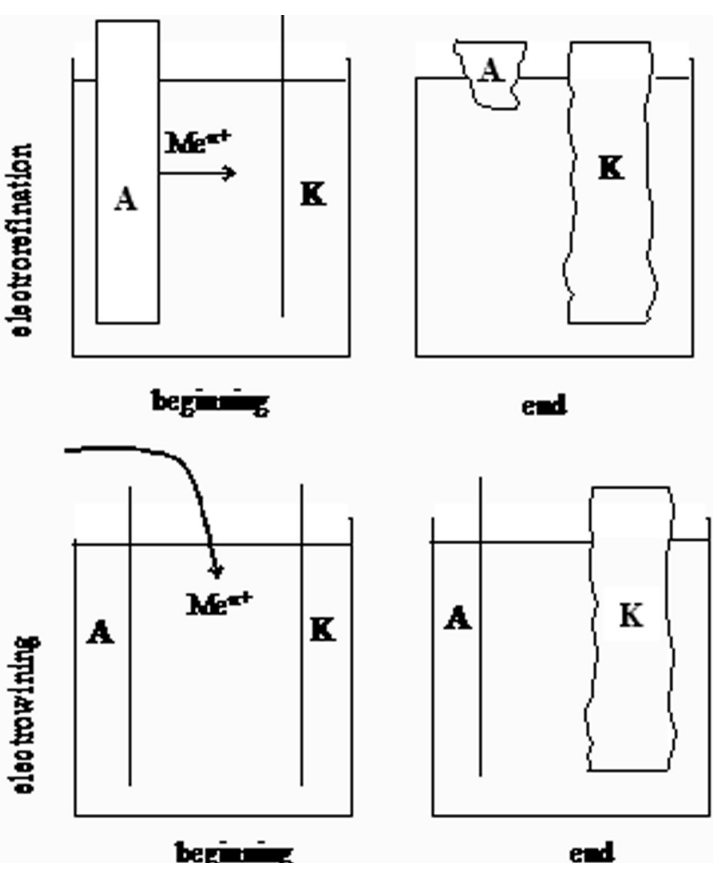

Fig. 2. Simplified schemes of electrorefination and electrowining processes

In the Figure 2 simple schemes of electrorefination and electrowining processes are shown for better understanding of the differences between them. In both cases cathodic process is metal ions reduction, i.e. electrodeposition of the metal. In order to produce polycrystalline and compact deposits, it is important to know the fundamentals of the electrocrystallization and the correlation between electrochemical parameters (overpotential, current density) and metal morphology. We address the readers to corresponding literature on electrochemical deposition of metals [1-3]. To produce purer and more compact metallic product, it is necessary to provide:

- better quality and arrangement of the electrodes. The purest deposit can be produced if electrodes are arranged vertically and maintain constant optimal distance between anode and cathode;

- optimal composition of the electrolyte to maintain both continuous constant supplying the cathodes with basic metal ions and low 
concentration of impurity metal ions. In the case of electrorefining, purification of the electrolyte should be performed in order to reduce the concentration of impurities and to avoid their deposition on the cathodic product. The concentration of the acid (mostly sulfuric acid) should be high enough to provide high electrical conductivity, i.e. lower Ohmic drop of the electrolyte. In order to smooth the metal deposit and to control the crystal growth, corresponding additives are used, e.g. gelatin as deposit smoother or thiourea and chloride ions as crystal growth regulators;

- optimal temperature. Heating the electrolyte causes higher electric conductivity and consequently lower energy consumption. Also, the solubility of the basic metal ions is higher and consequently their diffusion to the cathode is made easier, as well as the rate of the charge transfer on the cathode is higher. At higher temperatures electrolyte density and viscosity decrease that is suitable for avoiding particles of anode mud to be included into the cathodic product. But, the working temperature should have optimal value (not so high) due to evaporation of the electrolyte and higher energy consumption. In the case of electrowining of electronegative metals such as $\mathrm{Zn}$, In or $\mathrm{Cd}$, overpotential of hydrogen evolution on the cathode is made easier. The presence of hydrogen is very harmful for the cathodic product;

- optimal current density. At higher current density, electrodeposition is faster (desirable), but the dendritic growth is forced (undesirable). Dendritic deposits enslave electrolyte and anode mud particles more easily. Also, dendritic structure of metals is technically nonapplicable.

\subsection{Aqueous vs. molten salts electrolysis}

Electrolysis in aqueous electrolytes is a suitable process for metal production and refination at low temperature. As a result, cost-effective metal of high purity can be produced. The main solvent of the electrolytes for electrolysis is the water. There is not other solvent in electrochemistry that possesses unique water properties, such as:

- polarity - prerequisite for dissolving ionic compounds,

- electrolytic dissociation - prerequisite for better electric (ionic) conductivity of the electrolyte,

- stability (physical, chemical and thermal),

- wide interval of liquid state existence,

- non-toxic, non-corrosive and noncomplexable,

- availability and

- inexpensive.

But, electrolysis in aqueous electrolytes is limited to metals more positive than hydrogen such as $\mathrm{Cu}, \mathrm{Ag}, \mathrm{Au}$, and more negative ones that have high overpotential for hydrogen evolution such as $\mathrm{Zn}, \mathrm{Cd}$, In etc. The apparent electronegative metals such as $\mathrm{Na}, \mathrm{Mg}, \mathrm{Al}$, $\mathrm{K}$, Li can not be produced by electrolysis in aqueous solution because on the cathode only hydrogen evolution occurs. In order to reduce these metals on the cathode, $\mathrm{H}^{+}$ions have to be removed from the electrolyte, i.e. have to find other solvent which have above characteristics. Unfortunately, there is not some other inorganic or organic solvent with corresponding properties in industrial practice. So, the other approach to solve this problem is using molten metal salts. This is still a unique way for production of alkaline and alkaline earth metals ( $\mathrm{Na}, \mathrm{K}, \mathrm{Mg}$ ) and Al. Their oxides are very stable and their pyrometallurgical production is technically and commercially non-effective. Molten salt electrolysis has more disadvantages related to the aqueous electrolysis, such as:

- considerably higher working temperatures (up to $900{ }^{\circ} \mathrm{C}$ in case of $\mathrm{Al}$ ),

- complex composition of the electrolytes,

- highly-aggressive electrolytes, 
- complex electrode reactions,

- low current efficiency, i.e. high specific energy consumption and

- anodic effect - (stop of the current pass along with high rise of overvoltage, which causes breaking off of the electrolysis process.

\section{ECONOMIC / ENERGETIC ASPECTS}

Electrometallurgy is one of the highest consumers of energy within the global energy consumption. For illustration, two thirds of entire produced energy is consumed by the industry, while within the industry consumption, two thirds are consumed by the electrometallurgy. In Table 1 data about the energy consumption for production of the most important technical metals are shown [4].
In the time of enormous energy consumption, as well as the soon exhausting of the most used energent - fossil fuels, the present imperative of the electrometallurgy is the decrease of the energy consumption. To save energy consumption, it is important to know the specific energy consumption of electrolysis and structure of the applied voltage. Specific energy consumption $(w)$ is defined as a ratio of the energy consumption of the process $(W)$ and corresponding produced matter $(m)$ [5]:

$$
w=\frac{W}{m}=\frac{U \cdot I \cdot \tau}{I \cdot \tau \cdot q \cdot \eta_{i}}=\frac{U}{q \cdot \eta_{i}},\left(\mathrm{kWh} \cdot t^{-1}\right)
$$

where $U$ is the cell voltage; $I$ is corresponding current; $\tau$ is the time of electrolysis; $q$ is the electrochemical equivalent $\left(q=\frac{A}{z \cdot F}\right)$ depending on the atomic weight $(A)$ and valence $(z)$ of the produced metal as well as Faraday constant

$\mathrm{T}$ able 1

Products of the most massive electrolyses in the world and corresponding energy consumption

\begin{tabular}{ccccc}
\hline \hline Product (Year) & Type of electrolysis* & $\begin{array}{c}\text { World's annual } \\
\text { production } \\
1000 \mathrm{t}\end{array}$ & $\begin{array}{c}\text { Average } \\
\text { specific energy } \\
\text { consumption } \\
\text { kWh/t }\end{array}$ & $\begin{array}{c}\text { Total energy } \\
\text { consumption } \\
1000 \mathrm{kWh}\end{array}$ \\
\hline $\mathrm{Al}(2002)$ & $\mathrm{MSE}$ & 29,000 & 13,500 & 391,000 \\
$\mathrm{Mg}(2003)$ & $\mathrm{MSE}$ & 340 & 15,000 & 5,100 \\
$\mathrm{Cu}(2003)$ & $\mathrm{ER}$ & 11,200 & 300 & 3,360 \\
$\mathrm{Cu}(1999)$ & $\mathrm{EW}$ & 1,300 & 2,000 & 2,600 \\
$\mathrm{Zn}(2005)$ & $\mathrm{EW}$ & 6,400 & 3,500 & 22,400 \\
$\mathrm{Ag}(2005)$ & $\mathrm{ER}$ & 18,300 & 100 & 1,830 \\
$\mathrm{~Pb}(2003)$ & $\mathrm{ER}$ & 1,320 & 150 & 200 \\
$\mathrm{Ni}(2003)$ & $\mathrm{EW}$ & 504 & 4,000 & 2,020 \\
$\mathrm{Na}(2001)$ & $\mathrm{MSE}$ & 340 & 9,000 & 3060 \\
$\mathrm{Li}(2003)$ & $\mathrm{MSE}$ & 95 & - & - \\
$\mathrm{Cd}(2003)$ & $\mathrm{EW}$ & 16 & - & - \\
$\mathrm{Au}(2005)$ & $\mathrm{ER}$ & 2,5 & - & - \\
$\mathrm{Cl}(1999)$ & $\mathrm{EW}$ & 36,500 & 3,000 & 110,000 \\
\hline \hline
\end{tabular}

* - MSE - Molten Salt Electrolysis, ER - Electrorefination, EW - Electrowining 
$(F) ; \eta_{i}$ is the current efficiency. According to Eq. 1, the metal produced by electrolysis can be cheaper if the cell voltage $(U)$ is lower and the electrochemical equivalent and the current efficiency are higher.

Electrochemical equivalent $(q)$ is a characteristic value for each metal and varies only by valence state. Lower energy consumption can be achieved in the case of the lowest valence state of metal ions. For example, electrowining of copper by $\mathrm{Cu}^{+}$ions should be as twice efficient as by $\mathrm{Cu}^{2+}$ ions.

Current efficiency $\left(\eta_{i}\right)$ lowers when other electrochemical processes occur or some other energy losses happen. The average current efficiencies of electrometallurgical processes are in the range of $85 \div 95 \%$. To increase the energy savings, prevention of the above energy losses should be provided. To increase current efficiency, the following factors should be considered:

- high enough concentration of basic metal ions in the electrolyte to avoid deposition of metal impurities on the cathode,

- pure electrolyte, i.e. minimal concentration of impurity metal ions,

- optimal acidity of the electrolyte to improve its electrical conductivity,

- higher working current density at which current efficiency is higher,

- optimal working temperature of electrolysis. At higher temperatures electrical conductivity of the electrolyte and solubility of metal ions are higher as well as the diffusion of metal ions is faster. On the other hand, the overpotential of some undesirable reactions (such as hydrogen evolution) is lower. Thus, the optimal temperature at which current efficiency is the highest has some intermediate value,

- the presence of surface active substances to provide flat surface and to avoid inclusion of electrolyte and anodic slime particles on the metal deposit,

- avoiding short circuit between electrodes and other losses of energy through the conductors in the cell.
Cell voltage $(U)$ is the main parameter which directly affects the energy consumption of the electrolytic process. The lower the cell voltage is, the lower the specific energy consumption of the electrolysis. But, the cell voltage can not be lowered infinitely. So, the electrolysis has a minimal value of the cell voltage equivalent to the energy needed for the electrode reactions, i.e. summary chemical reaction. This is known as a theoretical voltage $\left(U_{\mathrm{S}}\right)$ of the cell. The cell voltage $(U)$ can be decreased by:

- proper choice of the electrode materials on which electrode reaction (cathodic and anodic) occurs by the lowest overpotential,

- proper cell design that provides minimal energy losses and

\section{- knowledge on the cell voltage structure.}

The first and second measures were discussed in the paragraph 1.2. The knowledge on the voltage components is very important in order to take action for decreasing them and consequently to decrease overall cell voltage. Beside the energy for the electrode reactions (anodic, $\eta_{\mathrm{a}}$ and cathodic, $\eta_{\mathrm{c}}$ overpotential), the applied overpotential contains other components such as Ohmic drop (IR) as result of electrical resistance of the electrolyte, energy to surmount diffusion limitations (diffusion overpotential, $\eta_{\mathrm{d}}$ ) energy for electrocrystallization and voltage as result of the resistance of the metal conductors, contacts, etc. The cell voltage structure can be expressed by the following equation:

$$
U=U_{S}+\left|\eta_{k}\right|+\left|\eta_{a}\right|+\sum\left|\eta_{d}\right|+\left|\eta_{k r}\right|+I R
$$

Except the theoretical voltage $U_{\mathrm{s}}$ which is a thermodynamic non-variable value, all other components can be varied (decreased) by controlling the electrolysis parameters.

In Table 2 the voltage structure and the specific energy consumption for electrorefination of copper and electrowining of copper are 
T a b 1 e 2

Cell voltage $U, V$ structure of the copper electrorefination and copper and zinc electrowining

\begin{tabular}{lccc}
\hline \hline Cell voltage components & $\begin{array}{c}\text { Electrorefining } \\
\text { Copper } \\
\left(20 \div 35 \mathrm{~mA} \cdot \mathrm{cm}^{-2}\right)\end{array}$ & $\begin{array}{c}\text { Copper } \\
\left(30 \mathrm{~mA} \cdot \mathrm{cm}^{-2}\right)\end{array}$ & $\begin{array}{c}\text { Zinc } \\
\left(45 \mathrm{~mA} \cdot \mathrm{cm}^{-2}\right)\end{array}$ \\
\hline $\begin{array}{l}\text { Theoretical voltage }\left(U_{\mathrm{S}}\right) \\
\begin{array}{l}\text { Overpotential: } \\
\text { anodic } \\
\text { cathodic }\end{array}\end{array}$ & 0 & 0.89 & 1.99 \\
\hline $\begin{array}{l}\text { Ohmic drop of the electrolyte } \\
(I \times R)\end{array}$ & 0.01 & 0.60 & 0.60 \\
\hline $\begin{array}{l}\text { Ohmic drop in the metal } \\
\text { conductors }\end{array}$ & 0.08 & 0.05 & 0.30 \\
\hline Ohmic drop in the contacts & 0.02 & 0.13 & 0.30 \\
\hline Total & 0.06 & 0.05 & 0.02 \\
\hline \hline
\end{tabular}

shown. It is noticeable that the electrorefination process consumes considerably less energy than electrowining. All other components of the cell voltage have similar values in both cases, except for the theoretical voltage. This difference in the cell voltage is due to the different nature of both processes. So, in the case of electrorefination there is not chemical transformation of the matter, because both, anodic and cathodic reactions are the same, occurring in opposite direction. Theoretical cell voltage defined as a sum of anodic and cathodic standard electrode potential, in the case of copper electrorefination is zero:

$$
U_{S}=E_{a}^{o}+E_{c}^{o}=E_{C u}^{o}+\left(-E_{C u}^{o}\right)=0
$$

In the case of electrowining, chemical transformation of the matter occurs, for example, $\mathrm{ZnSO}_{4}$ transforms to $\mathrm{Zn}$. Minimal energy needed for this transformation is above the theoretical cell voltage. Theoretical cell voltage for copper electrowining is $0.89 \mathrm{~V}$, while the corresponding value for zinc electrowining is even $1.99 \mathrm{~V}$. Thus, theoretical energy needs are higher in the case of electrowining than those in the case of electrorefining (see Figure 3). This implies higher specific energy consumption for electrowining compared to electrorefining process (see Table 3).

Analyzing the column for specific energy consumption in the Table 3 , it is noticeable that the electrolysis in molten salts is the largest energy consumer. For illustration, electrolysis parameters for zinc electrowining in aqueous electrolyte and aluminium electrowining in

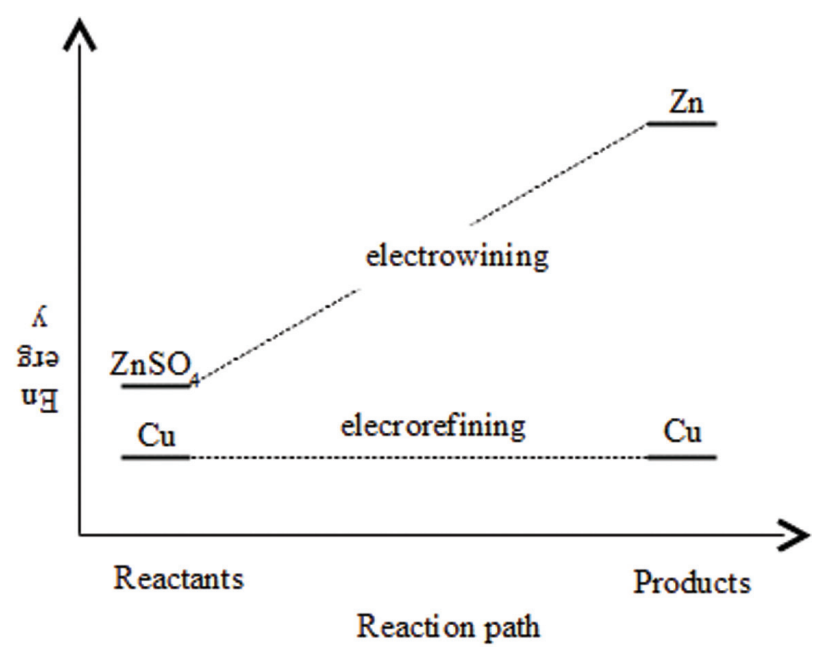

Fig. 3. Comparison of the energy change of electrorefination and electrowining 
T a b l e 3

Comparison of the electrolytic parameters of the aqueous electrowining of zinc and molten salt electrowining of aluminium

\begin{tabular}{lcccccc}
\hline \hline & $U_{\mathrm{s}} / \mathrm{V}$ & $U / \mathrm{V}$ & $i / \mathrm{mA} \cdot \mathrm{cm}^{-2}$ & $\eta_{\mathrm{i}}$ & $\mathrm{T} /{ }^{\circ} \mathrm{C}$ & $w / \mathrm{kWh} \cdot \mathrm{t}^{-1}$ \\
\hline Zinc & 1.99 & 3.3 & $40-70$ & 0.90 & $35-40$ & 3.500 \\
\hline \multirow{2}{*}{ Aluminium } & 2.89 & 4.5 & 6000 & 0.85 & 950 & 15.000 \\
\hline \hline
\end{tabular}

molten salt are given in Table 3 [6]. Specific energy consumption is more than five times higher for molten salt electrolysis of aluminium. This is a result of the following factors:

- higher theoretical cell voltage, due to considerably higher negative value of the standard electrode potential of aluminium and other overpotentials;

- high working temperature in the electrochemical cell $\left(\sim 950^{\circ} \mathrm{C}\right)$. To maintain this temperature, large quantity of energy is needed i.e. the electrolysis should be performed at higher current densities, even 100 times higher than corresponding ones during aqueous electrowining. These high current densities cause high specific energy consumption;

- interaction/oxidation of the produced metal with the molten salt which causes decrease of the current efficiency.

\section{ENVIRONMENTAL ASPECTS}

Compared to the pyrometallurgical metal production, electrometallurgy is considered as a "clean technology". Theoretically, electrolysis should not pollute the environment due to closed loop of the electrolyte cycling.

Nevertheless, there are several hot spots in electrometallurgical practice. Shown in Figure 4 is the scheme of the pollution sites in the electrometallurgical production of metals.

Mineral processing is the main source of the pollution. The minerals treatment from ore to pure electrolyte produces considerable quan- tity of solid, liquid and gaseous pollutants such as mine overburden, tailing ponds, wastewater, gases, smoke and dust. All of them contain heavy metals and are considered as hazardous waste.

The electrolysis plant is less polluting section compared to the mineral processing. There are two hot spots in the electrolysis plant: i) evaporation of the electrolyte and gaseous electrode products and ii) wastewaters.

During electrolysis, different gaseous products evolve and evaporation of the electrolyte occurs. Mainly oxygen and/or hydrogen and rarely chlorine or fluorine as gaseous products appears, while fine electrolyte drops evaporate during electrolysis. Proper ventilation has to be installed over the electrolytic cells to take away these pollutants and they must be further treated. In the case of molten salt electrolysis, the gaseous phase is more hazardous due to the presence of fluorine and gaseous fluorine compounds or chlorine and chlorine compounds.

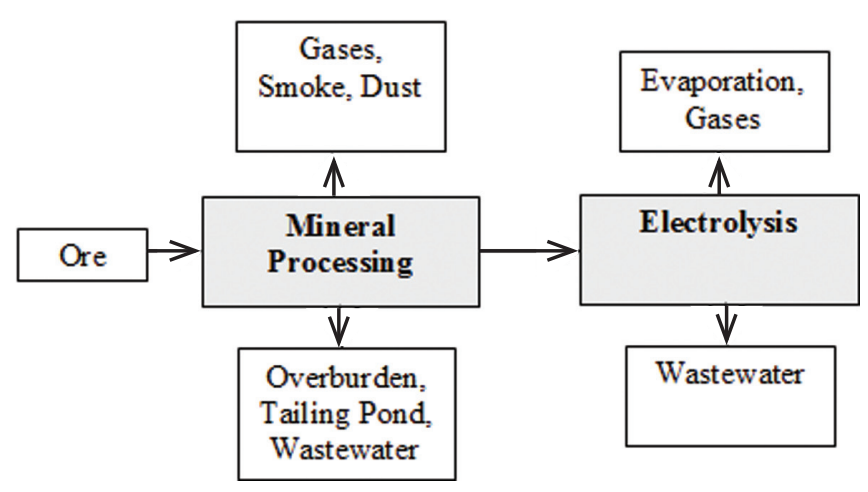

Fig. 4. Scheme of the pollution sites in the electrometallurgical production of metals 
Wastewater originates by the change of the used electrolyte and by the panning of the produced metal after electrolysis. This wastewater is acidic, containing heavy metals and different kind of anions. Wastewaters treatment includes neutralization process, performed by chemical deposition, extractive electrolysis and ion exchange in columns.

\section{REFERENCES}

[1] M. Paunović and M. Schlesinger, Fundamentals of Electrochemical Deposition, John Wiley \& Sons Inc., 1998.
[2] S. Djordjević, M. Maksimović, M. Pavlović, K. Popov, Galvanotehnika, Tehnička knjiga, Beograd, 1997.

[3] A. Milchev, Electrocrystallization-Fundamentals of Nucleation and Growth, Kluwer Academic Publishers, 2002.

[4] www.UNDP.com

[5] С. Хаџи Јорданов и П. Пауновиќ, Елекӣролиза

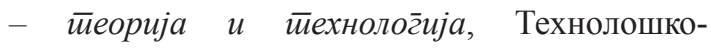
металуршки факултет, Скопје, 2008.

[6] K. I. Popov, B. N. Grgur, Osnovi elektrometalurgije, Tehnološko-metalurški fakultet, Beograd, 2002. 
